\title{
ORGANIZATIONAL CYNICISM AND EMPLOYEE PERFORMANCE OF LOGISTICS COMPANIES IN SOUTHWEST NIGERIA
}

\author{
Chidinma M. Dimgba, Micheal A. Ikon, Ph.D. and Faith Chidi Onwuchekwa PhD \\ Department of Business Administration, Faculty of Management Sciences, Nnamdi Azikiwe \\ University Awka, Anambra State
}

Citation: Chidinma M., Dimgba, Micheal A., Ikon and Faith Chidi Onwuchekwa (2022) Organizational Cynicism and Employee Performance of Logistics Companies in Southwest Nigeria, European Journal of Business and Innovation Research, Vol.10, No.1, pp. 18-34,

\begin{abstract}
The broad objective is to ascertain the extent of relationship between Organizational Cynicism and Employee Performance of Logistics Companies in South West, Nigeria. The specific objective is to ascertain the extent of relationship between workplace bullying and Employee Turnover. The study was anchored on Social Exchange theory and Conservation of Resources Theory propounded by Stevan Hobfoll in (1989). Sixty Haulage Logistics Companies was selected from Lagos, Oyo and Ogun, the Population of the Study is 4,560, sample size of 380 and Pearson Moment Correlations Co-efficient was used to analyze the data. It was revealed through the findings that there is a significant positive relationship between Workplace Bullying and Employee Turnover since (Cal.r.602 >Crit.r.087). The study concludes that Organizational Cynicism have a significant positive relationship with Employee Performance and the study recommends that, logistics companies should put a control measure in place to checkmate workplace bullying so as to reduce cynicism.
\end{abstract}

KEY WORDS: organizational cynicism, employee performance.

\section{INTRODUCTION}

Employees of an organization is substantial as they spend maximum productive time in the office. Healthy relationships among employer and employee would boost energy and efficiency, while a toxic relationship could breed inefficiency and ineffectiveness on the job, thereby reducing employee performance. Ghadeer (2016) viewed organization cynicism as a job attitude that involves frustration and a set of negative feelings towards the distrust of a person or a group or an object. Organization Cynicism is one of the important job attitudes which affect directly the employees' behaviorural patterns towards goals' achievement. Cynicism could be described as one being pessimistic, and undesirable view about others. Employees who are cynical can influence the whole organization and can hamper the organization from reaching its goals (Rehna, Iqbal, Fatima \& Nawab, 2017). Workplace bullying involves circumstances where employees receive aggressive, intimidating and harmful behaviour on continuous basis, which has

ECRTD-UK https://www.eajournals.org/

ULR: https://doi.org/10.37745/ejbir.2013 
embarrassing, harsh, or terrifying effect on employees experiencing such behaviors (leymann, 2008). According to Kuo et-al (2011), employee performance can be identified as workers total delivery in meeting expected worth and tasks under the given procedures and timelines. Bullying has being a deliberate issue that occurs in every organization either by the employer or employee, raging work load, untimely deadlines, teasing, passing disrespectful comments, playing impractical jokes on different employees are traits of bullying which can lead to cynicism behavior by the employees towards the employer due to the bad treatment or comments.

Seeming organizations face these problem of cynicism behavior by employees due to negative feelings, exhaustion and fatigue, lack of promoting, bridging of contract and bullying. These leads to cynicism behaviors against the organization and reduce employee performance. It is on this milieu of issues the researcher endeavors to study the relationship that exists between organizational cynicism and employee performance of Logistic Companies in South West, Nigeria. Specifically, this study seeks to identify the extent of relationship between workplace bullying and employee performance of Logistics Companies in South West, Nigeria

\section{Research Question}

What is the relationship between workplace bullying and employee turnover?

\section{Research Hypothesis}

Ho: workplace bullying has no significant relationship with employee turnover of Logistics Company in South West, Nigeria

\section{REVIEW OF RELATED LITERATURE}

\section{Organizational Cynicism}

Organizational cynicism is an outcome of an employees' belief that organizations lack honesty, expectations of morality, justice, and honesty are violated. (Wageeh and Belal, 2013).

Ozler, Derya, Giderler and Sahin (2010) defined cynicism as individuals having negative feelings, such as disappointment, anger, insecurity, hopelessness, which brought about many difficulties both for the staff and organizations. According to Aly, Ghanem and El-Shanawany (2016), cynicism is referred to as being negative and doubtful about others, an entire organization can be influenced by cynical employees and can hamper the organization from realizing its goals

Lubna, Engy and Ghadeer (2018) aver that organizational cynicism is a negative attitude toward one's employing organization, comprising three dimensions: (1) a belief that the organization lacks integrity; (2) negative affect toward the organization; and (3) tendencies to disparaging and critical behavior toward the organization that are consistent with these beliefs. Cynicism is the attitude of the individual in which they are pessimistic about their latent purposes, they explain things based on disappointment, and their tendency is to pay attention to others as an instrument to take care or increase their interest (Stanley, Meyer \& Topolnytsky, 2005)

ECRTD-UK https://www.eajournals.org/

ULR: https://doi.org/10.37745/ejbir.2013 
Cynicism is of three dimensions such as

- The Cognitive Dimension: the belief that the organization lacks moral attitudes. Referring to the lack of sincerity, honesty, and justice. Cynics also believe that all these principles are absent and that all human beings are dishonest and incomprehensible.

- The Affective Dimension: the strong emotional reaction towards the organization. Cynics are disrespectful toward their organization and may feel ashamed of working for such an entity.

- The Behavioral Dimension: tends to criticize the organization frequently. However criticizing may occur in various forms but it's mostly about the organizations lack of honesty.

Organizational Cynicism more or less leads to employee demotivation. Once employees are demotivated employee performance drops.

\section{Employee Performance}

Employee performance is a vital indicator of any organization success or failure, it is a significant indicator for organizations, in attainment of their objectives or goals in both developed and developing businesses (Shafique-ur, Rapiah \& Hazeline 2019) most companies are seeking to improve their performance in any way possible. The winning card can be held by those who endeavor to innovate, to obtain and sustain performance. Thus, competing in a continuously changing environment which is very necessary to comprehend and monitor performance (Omar \& Zineb 2019).

Tomal and Jones (2015), define employee performance as the actual results or output of an organization as measured against organization's intended outputs. Performance is the result of work of a person or group in an organization at a particular time which reflects how well the person or group reach the qualification of a job in a mission of organization's goal achievement (Khaled \& Haneen, 2017). Performance is the goal achievement of an organization rather than of individuals, with the minimum resources consumed to reach the goal (Ghalem, 2016).

Edogbanya and Momodu( 2019) organizations with a committed workforce tend to experience stronger work teams, improved performance, increased profitability, lower turnover, and increased efficiency. Nevertheless, the task most organizations face focuses on how to attain improved commitment in the face of growing negative employee attitudes. Cynicism is one such negative employee attitudes

\section{Workplace Bullying}

Bullying is defined as a process in which an employee is repeatedly and systematically exposed to negative behaviors that he or she is unable to defend against (Einarsen, Hoel, Zapf, \& Cooper, 2011). Workplace bullying is a repeated mistreatment of one employee who is targeted by one or more employees with a malicious mix of humiliation, embarrassment, intimidation and sabotage of performance (Margaret, 2007). Workplace bullying is about a personalized, often sustained attack on one colleague by another colleague using behaviors which are emotionally and

ECRTD-UK https://www.eajournals.org/ 
psychologically punishing (Arynne, 2009). According to Swathi (2017) workplace bullying constitutes any persistent behaviors, unwanted, offensive, humiliating behaviors towards an individual or group of employees. Instead of using physical means, however, workplace bullies often operate within an established rules and policies of the organization or the society. Bullying in the workplace is covertly accepted by the management and directed toward a person who is unable to defend himself or herself because of his or her lower rank and position in the organization. "Managers and supervisors identified as participating in bullying behavior were reportedly rewarded with promotions ,biggest bully gets the best promotion every time and bullies are protected and moved into higher better paying positions for their inappropriate behavior (Hutchinson \& Jackson, 2014,)

Mariya and Usman (2014), opined that bullying is a malicious act, the victims that are subjected to such acts have to face harmful consequences. Generally, bullying acts are complex in nature because they refer to almost invisible and non-physical form of violence which can be overt or covert and has the potential to cause minor severe harm, irrespective of the manner these behaviors are conducted, such acts are done recurrently to inflict harm upon the person they are directed at. Shehnaz and Sadia (2013), workplace bullying consists of any irregular behavior, unnecessary, unpleasant, shameful behaviors towards an individual or group of employees. Bullying include being rude and uncivil behavior, bullying is distinctly different, bullying is intense, specifically directed towards a target and is repetitive (Jillian, 2018). Faran (2018), posit that a positive workplace culture leads to increased productivity, better employee morale, negative attitudes in the workplace always lead to bullying prospective. Engage your employees in daily operations of the company

\section{Employee Turnover}

Employee turnover intention is an element that affects employee productivity. Chen, (2008), defined employee turnover as "employee's desire or willingness to leave an organization" or it is a process in which staff of the organization or business leave that organization or business, employees plan to leave their positions, it may be voluntary or involuntary. Saeed, Waseem, Sikander, and Rizwan. (2014) explain turnover of an employee as the rotation of workers between the condition of employment and unemployment, jobs and occupations around the labor market and firms. Tandung (2016), pressed that employee turnover is the relative strength of an individual's purpose or intent toward voluntary permanent withdrawal from an organization. It is basically a motive or purpose that drives an employee to quit from his or her current workplace.

Noermijati and Azzuhri (2018) stated that employees who have high organizational commitment are expected to have a high sense of belonging to the organization. In other words, these attitudes

ECRTD-UK https://www.eajournals.org/

ULR: https://doi.org/10.37745/ejbir.2013 
reflect employee loyalty to the organization that is a continuous process. The employees' participation expresses their concern for organization success and survival. According to Akhtar, Ghufran, and Fatima (2017), opined that turnover is the ratio of the total number of employees who quits an organization at a particular time period with the average number of employees staying in that organization at the same time. It is a behavior which describes the process of leaving or replacing employees in an organization. Employee turnover tends to incur a direct cost such as exit interview time, administrative requirements, cost of temporary workers, recruitment, selection and formal and informal training of the new employee until he attains performance level equivalent to the one who quits (Niharika, 2014).

\section{THEORETICAL REVIEW}

This study is anchored on social exchange theory shows the relationship between the cost and benefits of an individual what he expects (Emerson, 1976). So if an employee face high cost like putting high effort and getting less benefits so this create dissatisfaction towards job and Conservation of Resources (COR) Theory. Conservation of Resources (Cor) Theory is a stress theory that describes the motivation that drives humans to both maintain their current resources and to pursue new resources. This theory was proposed by Stevan E. Hobfoll in 1989 as a way to expand on the literature of stress as a construct. Hobfoll (1989), posited that psychological stress occurred in three instances; when there was a threat of a loss of resources, an actual net loss of resources, and a lack of gained resources following the spending of resources. From this perspective, resources are defined as things that one values, specifically objects, states, and conditions. (Halbesleben et al., 2014). COR states that loss of these types of resources will drive individuals into certain levels of stress. (Hobfoll, 1989). This theory is relevant to this study because when resources (employees) are properly handled, it could impact the performance level of employees.

\section{Empirical Review}

Muhammad (2014), uncover the effect of organizational cynicism on employee turnover Intention: evidence from Banking Sector in Pakistan. The literature on organizational cynicism and turnover intention demonstrates that cynicism has profound effects on turnover intention and job satisfaction and intrinsic motivation as mediating variables were also investigated. Questionnaire from 250 employees functioning on various positions in domestic private sector banks from two cities of Pakistan (Rawalpindi/Islamabad) were used. Data was analyzed using SPSS Version 17. The Correlation analysis, Regression analysis and Baron and Kenny three step mediation techniques were used to analyze the results. The findings concluded that job satisfaction and intrinsic motivation partially mediates the relationship between organizational cynicism and turnover intention. To cope with the recent challenges management must create an atmosphere

ECRTD-UK https://www.eajournals.org/

ULR: https://doi.org/10.37745/ejbir.2013 
within the banks to improve employees' intrinsic motivation to reduce cynicism behavior and turnover intention among employee.

Mariya and Usman (2014), studied the effect of workplace bullying on turnover Intention of faculty members: a case of private sector universities of Khyber Pakhtunkhwa, The twofold objectives of this paper were to measure the overall level of bullying prevalent within the sample and the relationship between exposure to bullying behaviors and intention to quit that workplace. Survey research method was used, 207 questionnaires were distributed among the teaching staff of academic universities within the private sector of Peshawar city, and regression analysis was adopted. The findings of this study revealed that exposure to workplace bullying indeed leads to "intention to quit" of those exposed The level of workplace bullying was found to be low but a significant positive relationship was found between workplace bullying and intention to quit Gap in knowledge to target the private sector.

Edip and Alev (2016) studied the influence of workplace bullying on employee's job performance, job satisfaction and turnover intention in a newly established private hospital in province of Ankara, Turkey. The Objective was to examine the effects of workplace bullying among the healthcare staff on the job performance, job satisfaction and turnover intention. The path analysis modeling the data compiled within the scope of the study were analyzed and interpreted in line with the determined objectives by using the descriptive statics and employing various statistical analyses (frequency analysis, correlation analysis, t-test, one-way analysis of variance, multiple comparison test and structural equation modeling) questionnaires were distributed to 171 health staffs in the hospital, SPSS 21 package software was utilized. From the findings it was determined that there was a positive relationship between the workplace bullying behaviors towards the individuals and the turnover intention, whereas a negative relationship was observed between the workplace bullying and the job performance. In addition, a negative relationship was determined between job satisfaction and turnover intention.

Jayasekara and Seneviratne (2019), examined the relationship between organizational cynicism and employee performance at diverse hierarchical levels in four audit firms in Sri Lanka. Quantitative research methodology and questionnaires were used as a primary data collection method from audit trainees, audit supervisors, and audit managers in big 4 audit firms in Sri Lanka. Convenient sampling technique, and regression models were used by applying SPSS. The study found a significant negative relationship between organizational cynicism and employee performance at audit firms and that each dimension of organizational cynicism. Organizational cynicism can hamper the performance of employees, when organization don't keep their part of their bargain with the employee.

Maria, Muhammad and Shahpara (2018), opined that workplace bullying can ground cynicism between the employees. It observe the motives of bullying and the way it can be resolved. The

ECRTD-UK https://www.eajournals.org/

ULR: https://doi.org/10.37745/ejbir.2013 
look at explored the effect of workplace bullying on employee's cynicism and psychological contract. Facts were examined through Statistical bundle for Social Sciences (SPSS) model 24 and Cronbach's Alpha was used to test reliability. The data comprised 150 employees working within the textile sector of Faisalabad. The results of this study showed that there is a significant relationship among workplace bullying and employee cynicism. The effects additionally suggest that the relationship among workplace bullying and employee cynicism may be in part mediated by psychological contract. Employers should endeavor to place rules/ policies that will foster bullying so as not to lead to employee cynicism.

Seifolahi and Hassanzadeh (2018), investigated the effect of organizational cynicism on the bullying of the workplace among the employees of the center and five areas of municipality of Rasht. The research method is descriptive and correlational. Data was collected using a questionnaire and survey method. The statistical population consists of all managers and staff of the center and five areas of the municipality of Rasht. Data were collected from sample of 317 managers and employees of the municipality of Rasht by stratified random sampling. Data were collected using two standard questionnaire of organizational mistrust (independent variable) and workplace bullying (dependent variable) and analyzed using LaserL software 8. 54. Findings using structural equation model and test indicate that cognitive dimension (destructive beliefs and beliefs) and behavioral dimension (degrading and malicious behaviors) organizational cynicism have a positive effect on the occupational environment and increase the incidence of this behavior in the organization and emotional dimension (negative emotions) does not significantly affect bullying in the workplace.

\section{Gap in Knowledge}

None of the empirically reviewed examined organizational cynicism as it relates directly to bullying, organization of study and employee performance of logistic companies in South-West, Nigeria. This is the gap in knowledge that this study seeks to fill.

\section{METHODOLOGY}

\section{Research Design}

The study adopted survey research design method. Survey research design is used to quantitatively describe specific aspects of a given population. It was used because it aids the collection of data from the sampled respondents without influencing the results.

\section{Population of the Study.}

Base on the area of study the logistic companies can be found in South West Nigeria, which are predominantly located at Lagos State, Oyo State and Ogun State. Having been represented of

ECRTD-UK https://www.eajournals.org/

ULR: https://doi.org/10.37745/ejbir.2013 
European Journal of Business and Innovation Research

Vol.10, No.1, pp. 18-33, 2022

Print ISSN: 2053-4019(Print),

Online ISSN: 2053-4027(Online)

Haulage Logistic Companies in South West Nigeria. The total population of the selected logistic companies in afore mention state (Lagos, Oyo and Ogun) is 4,560.

\section{Sample Size and Sampling Technique}

Simple random sampling technique was adopted together in the selection process. To ensure adequate coverage, Stratified sampling technique was utilized, the states in the south west that was used are (Lagos, Oyo and Ogun) could be considered. The sample size of study 380, was determined using Krejcie and Morgan (1970) Formula and Bowley's Proportional Population Allocation Formula (1926); was adopted to distribute the 380. Primary source of data was adopted Questionnaire to the respondent.

\section{Description of Data Collection Instrument}

Questionnaire was designed on a 5-point Likert scale, Strongly Agree (5), Agree (4), Disagree (3) and Strongly Disagree (2) Undecided (1), so as to elicit relevant information from the respondents, consisting of independent and dependent variables capturing 40 questions, for each variables was measured with (5) items each and Eight specific variables to be measured.

Table 3.6: Questionnaire Allocation and Retrieval Instrument.

\begin{tabular}{|l|l|l|l|l|}
\hline & NAME OF LOGISTICS COMPANY & POPULATION & No distributed & $\begin{array}{l}\text { No Collected / } \\
\text { Analyzed }\end{array}$ \\
\hline 1 & BOWA GATES GLOBAL LIMITED & 100 & 8 & 8 \\
\hline 2 & SWISSDARL FREIGHT ANDLOGISTICS & 80 & 7 & 6 \\
\hline 3 & $\begin{array}{l}\text { AAROCO GLOBAL TRANS AND } \\
\text { LOGISTICS SERVICES }\end{array}$ & 60 & 5 & 5 \\
\hline 4 & NONNY GLOBAL & 70 & 6 & 5 \\
\hline 5 & TEAM FREIGHT LIMITED & 50 & 4 & 4 \\
\hline 6 & $\begin{array}{l}\text { RIT JOSE FREIGHT AGENCIES } \\
\text { NIGERIA LTD }\end{array}$ & 70 & 6 & 5 \\
\hline 7 & HOME LAND CARGO SERVICES LTD & 70 & 6 & 6 \\
\hline 8 & ALOV AIR SEA LIMITED & 80 & 7 & 7 \\
\hline 9 & SAIMA NIGERIA & 60 & 5 & 4 \\
\hline 10 & KINGS LOGISTICS & 60 & 5 & 4 \\
\hline 11 & EMRY FREIGHT NIGERIA LTD & 100 & 8 & 7 \\
\hline 12 & OREGUN FREIGHT HANDLING LTD & 100 & 8 & 7 \\
\hline 13 & CHUKABEN AGENCIES NIGERIA LTD & 80 & 7 & 5 \\
\hline 14 & DISTINCT CUSHY FREIGHT & 100 & 8 & 7 \\
\hline 15 & COLLOSSIANS INTERNATIONAL & 80 & 7 & 6 \\
\hline 16 & CHIBYKE GLOBAL & 60 & 5 & 4 \\
\hline
\end{tabular}


European Journal of Business and Innovation Research Vol.10, No.1, pp. 18-33, 2022

Print ISSN: 2053-4019(Print),

Online ISSN: 2053-4027(Online)

\begin{tabular}{|c|c|c|c|c|}
\hline 17 & $\begin{array}{l}\text { VALUEHANDLERINTERNATIONALLT } \\
\text { D }\end{array}$ & 50 & 4 & 4 \\
\hline 18 & $\begin{array}{|lccc|}\text { REDOX } & \text { CORP } & \text { SHIPPING } & \text { AND } \\
\text { LOGISTICS LTD } & & \\
\end{array}$ & 100 & 8 & 7 \\
\hline 19 & CONFIDENCE CARGO LT & 50 & 4 & 4 \\
\hline 20 & DELAR FREIGHTS AND LOGISTICS & 60 & 5 & 4 \\
\hline 21 & PROFESSIONAL SHIPPING LOGISTICS & 70 & 6 & 5 \\
\hline 22 & \begin{tabular}{|l} 
FLO CARGO \\
\end{tabular} & 100 & 8 & 8 \\
\hline 23 & OPTIDAR NIGERIA LTD & 120 & 10 & 9 \\
\hline 24 & BRANDVIEW LIMITED & 60 & 5 & 4 \\
\hline 25 & AFRILINK EXPRESS SERVICES & 80 & 7 & 6 \\
\hline 26 & \begin{tabular}{|l} 
KNIGHTSBRIDGE LOGISTICS \\
\end{tabular} & 90 & 8 & 7 \\
\hline 27 & \begin{tabular}{|l} 
EMIROS CARGO LTD \\
\end{tabular} & 100 & 8 & 7 \\
\hline 28 & EAGLE EYES SHIPPING LTD & 100 & 8 & 7 \\
\hline 29 & \begin{tabular}{|l|l|} 
FREIGHT LINER LOGISTICSSERVICES \\
\end{tabular} & 50 & 4 & 4 \\
\hline 30 & OPTIDAR NIGERIA LIMITED & 60 & 5 & 5 \\
\hline 31 & CARGOLAND MARITIME SERVICES & 80 & 7 & 6 \\
\hline 32 & 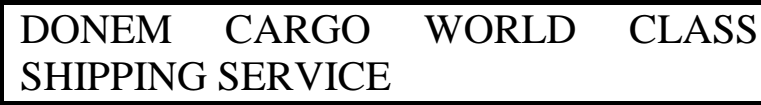 & 60 & 5 & 5 \\
\hline 33 & BRIGHT EMINENT INTERNATIONAL & 50 & 4 & 4 \\
\hline 34 & ELVYTEX GLOBAL LINKS & 50 & 4 & 4 \\
\hline 35 & HUMBLE GLOBAL LOGISTICS LTD & 50 & 4 & 3 \\
\hline 36 & VALROXX LOGISTICS & 40 & 3 & 3 \\
\hline 37 & \begin{tabular}{|l} 
MERCY EXPRESS FREIGHT LTD \\
\end{tabular} & 80 & 7 & 6 \\
\hline 38 & \begin{tabular}{|l} 
KEN RELOCATION COMPANY \\
\end{tabular} & 70 & 6 & 5 \\
\hline 39 & R2W GLOBAL SERVICES LTD & 60 & 5 & 5 \\
\hline 40 & CARGO ZEAL TECHNOLOGY LTD & 70 & 6 & 6 \\
\hline 41 & LECHWE MARITIME \& LOGISTICS & 90 & 8 & 8 \\
\hline 42 & \begin{tabular}{|l|} 
SKB LOGISTICS NIGERIA \\
\end{tabular} & 40 & 3 & 3 \\
\hline 43 & \begin{tabular}{|l} 
BATOLAB NIGERIA LIMITED \\
\end{tabular} & 50 & 4 & 4 \\
\hline 44 & FEMINIS LOGISTICS LIMITED & 60 & 5 & 4 \\
\hline 45 & DATOL EXPRESS COURIER SERVICE & 40 & 3 & 3 \\
\hline 46 & GIMMS LINK GLOBAL LOGISTICS & 80 & 7 & 6 \\
\hline 47 & MAIL IMPEX GLOBAL RES. NIG. LTD & 50 & 4 & 4 \\
\hline 48 & \begin{tabular}{|l} 
JAHLIVE SADAKKA NIGERIA LTD \\
\end{tabular} & 50 & 4 & 4 \\
\hline 49 & TRUTH KEY NIGERIA LTD & 50 & 4 & 4 \\
\hline 50 & TRUCKWAYS & 120 & 10 & 10 \\
\hline 51 & SAGAMU GLOBAL WINGERS LTD & 100 & 8 & 7 \\
\hline
\end{tabular}

ECRTD-UK https://www.eajournals.org/

ULR: https://doi.org/10.37745/ejbir.2013 
European Journal of Business and Innovation Research

Vol.10, No.1, pp. 18-33, 2022

Print ISSN: 2053-4019(Print),

Online ISSN: 2053-4027(Online)

\begin{tabular}{|l|l|l|l|l|}
\hline 52 & BHN LOGISTICS & 150 & 13 & 13 \\
\hline 53 & MUSHILAB NIGERIA LTD & 80 & 7 & 6 \\
\hline 54 & TEEJAY PETROLEUM CO. LTD & 70 & 6 & 5 \\
\hline 55 & DEOMAT NIGERIA LTD & 150 & 13 & 13 \\
\hline 56 & $\begin{array}{l}\text { EWEKORO WORKS CEMENT STAFF } \\
\text { COOP. }\end{array}$ & 250 & 21 & 21 \\
\hline 57 & SWIFT CHARIOT TANSIT SERVICES & 60 & 5 & 5 \\
\hline 58 & TIDE EXPRESS LINK & 50 & 4 & 4 \\
\hline 59 & K-BROWN LOGISTIC \&MERCHADISE & 50 & 4 & 4 \\
\hline 60 & GIRTEKA LOGISTIC & 50 & 4 & 4 \\
\hline & Total & $\mathbf{4 , 5 6 0}$ & $\mathbf{3 8 0}$ & $\mathbf{3 5 0}$ \\
\hline
\end{tabular}

Source Field Survey, Haulage and Logistics Magazine, 2021 and Bowley's Allocation Formula Application.

Table 3.6 shows the allocation and retrieval of instrument from the respondent using Bowley's proportional population allocation formula (1926); which was adopted to distribute numbers of instrument for each logistic company's base on the populations. 380 questionnaires were distributed to all the 60 logistics companies, 350 questionnaires was collected and analyzed for the study.

\section{Reliability of the Instrument}

Reliability measures the consistency level of the research instrument and was carried out using Test Retest Reliability test was used, questionnaire representing $20 \%$ of the population were distributed, collected, coded and analyzed. The result obtained was 0.79 which is greater than the bench mark of .50. The instrument was therefore adjudged to be reliable.

\section{Method of Data Analysis}

Pearson's Product Moment Correlation Coefficient will be used in analyzing the data which is to explore the relationship between organizational cynicism and employee performance of Logistics Companies in South West, Nigeria. The level of significance used will be 5\% and the confidence interval 95\%. The correlation coefficient will be carried out with the aid of SPSS Statistical Software Package Version 10. 
European Journal of Business and Innovation Research

Vol.10, No.1, pp. 18-33, 2022

Print ISSN: 2053-4019(Print),

Online ISSN: 2053-4027(Online)

\section{DATA PRESENTATION AND ANALYSIS}

Descriptive statistics of question items of Workplace Bullying and Employee Turnover of Logistic Companies in South West, Nigeria

\begin{tabular}{|c|l|r|r|}
\hline S/N & Workplace Bullying & \multicolumn{1}{|c|}{ Mean } & \multicolumn{1}{|c|}{$\begin{array}{c}\text { Deviation } \\
\text { Dever }\end{array}$} \\
\hline 1. & Have been humiliated/ ridiculed before my colleagues & 4.4857 & .87537 \\
\hline 2. & I feel cheated here due to the treatment I receive & 4.5143 & .69263 \\
\hline 3. & $\begin{array}{l}\text { Am helpless when performing my task due to ash answers I } \\
\text { receive when I ask questions, which affect my productivity }\end{array}$ & 4.1714 & .81130 \\
\hline 4. & $\begin{array}{l}\text { You are being shouted at for asking for my entitlement as } \\
\text { agreed before employment. }\end{array}$ & 4.7143 & .51183 \\
\hline 5. & $\begin{array}{l}\text { Am being ordered to do work below your level of } \\
\text { competence }\end{array}$ & 4.8000 & .40057 \\
\hline & $\begin{array}{l}\text { Employee Turnover } \\
\text { It is very possible that I will look for a new job soon. }\end{array}$ & 4.8000 & .40057 \\
\hline 2. & Am leaving because hostile attitude I get & 4.7143 & .45240 \\
\hline 3. & $\begin{array}{l}\text { If I may choose again, I will choose to work for the current } \\
\text { organization. }\end{array}$ & 2.2571 & .43768 \\
\hline 4. & Am leaving due to the organizations structure. & 4.8571 & .35043 \\
\hline 5. & Am leaving because I got a better offer. & 4.4857 & .96860 \\
\hline
\end{tabular}

Source: Field Survey (2021), Computation: SPSS Ver.2023

Table: 4.1. Shows the descriptive statistics for each research question

4.1.2 Correlation Result for Objective Four

\begin{tabular}{|ll|r|r|}
\hline & \multicolumn{1}{|c|}{$\begin{array}{c}\text { Workplace } \\
\text { Bullying3 }\end{array}$} & $\begin{array}{c}\text { Employee } \\
\text { Turnover3 }\end{array}$ \\
\hline Workplace & Pearson & 1 & $.602^{* *}$ \\
& Correlation & & .000 \\
Sig. (2-tailed) & & 350 \\
Employee & $\mathrm{N}$ & 350 & 1 \\
Turnover3 & Pearson & $.602^{* *}$ & \\
& Correlation & & 350 \\
& Sig. (2-tailed) & .000 & \\
& $\mathrm{~N}$ & 350 & \\
\hline
\end{tabular}

**. Correlation is significant at the 0.01 level (2-tailed).

ECRTD-UK https://www.eajournals.org/

ULR: https://doi.org/10.37745/ejbir.2013 
Table 4.4.2. Shows the correlation coefficient for workplace bullying and employee turnover of Logistics Company in South West, Nigeria. The result indicates that there is a positive relationship between the variables with a correlation coefficient of .602

\section{DISCUSSION OF FINDINGS}

The tested hypothesis, shows a positive significant relationship between workplace bullying and employee turnover of Logistic Companies in South West, Nigeria (Cal.r.602 >Crit.r.087). The result indicates that workplace bullying has a high relationship with employee turnover, hypothesis and level of significance were tested, it was positive. Therefore these findings support Muhammad (2014), uncovering the effect of organizational cynicism on employee turnover Intention: evidence from Banking Sector in Pakistan. The literature on organizational cynicism and turnover intention demonstrates that cynicism has profound effects on turnover intention and job satisfaction and intrinsic motivation as mediating variables were also investigated. Using correlation analysis, Regression analysis and Baron and Kenny three step mediation techniques were used to analyze the results. The findings concluded that job satisfaction and intrinsic motivation mediates the relationship between organizational cynicism and turnover intention.

Seifolahi and Hassanzadeh (2018), investigated the effect of organizational cynicism on the bullying of the workplace among employees of the center and five areas of municipality of Rasht. Data were collected using two standard questionnaire of organizational mistrust (independent variable) and workplace bullying (dependent variable) and analyzed using LaserL software 8. 54. Findings using structural equation model and test indicate that cognitive dimension (destructive beliefs and beliefs) and behavioral dimension (degrading and malicious behaviors) organizational cynicism have a positive effect on the occupational environment and increase the incidence of this behavior in the organization and emotional dimension (negative emotions) does not significantly affect bullying in the workplace but organizational cynicism has a relationship with bullying and Mariya and Usman (2014), study on effect of workplace bullying on turnover Intention of faculty members: a case of private sector universities of Khyber Pakhtunkhwa, measure the overall level of bullying prevalent within the sample and the relationship between exposure to bullying behaviors and intention to quit that workplace. The study revealed that exposure to workplace bullying indeed leads to intention to quit, there is a significant positive relationship between workplace bullying and intention to quit. Organizations should strategize ways of fostering unwanted behaviors and humiliating behaviors towards an employee these would lead to employee turnover which is not health for the company's image.

\section{CONCLUSION}

The specific objective of the study was to determine the relationship that exists between workplace bullying and employee turnover of Logistic Companies in South West, Nigeria. The study

ECRTD-UK https://www.eajournals.org/

ULR: https://doi.org/10.37745/ejbir.2013 
European Journal of Business and Innovation Research

Vol.10, No.1, pp. 18-33, 2022

Print ISSN: 2053-4019(Print),

Online ISSN: 2053-4027(Online)

concludes that there is significant positive relationship between workplace bullying and employee turnover of the studied firms.

\section{Recommendations}

Analysis result showed that workplace bullying has a positive relationship with employee turnover, thus coping with the recent challenges management must create an atmosphere within the company to improve employee's motivation to reduce cynicism behavior and turnover intention among employee, logistics companies should put a control measure in place in checkmate workplace bullying so as to reduce cynicism and meet every contract agreed with employees, which will lead to employee performance.

\section{References}

Aly, N. M., Ghanem, M., \& El-Shanawany, S. (2016). Organizational Cynicism and its Consequences on Nurses and Quality of Care in Critical Care and Toxicology Units. Journal of Education and Practice, Vol 7(8).

Anitha, J. (2014). Determinants of employee engagement and their impact on employee Performance. International Journal of Productivity and Performance Management, Vol 63(3), Https://doi.org/10.1108/ijppm-01-2013-0008

Aryanne O. (2009). Managing Workplace Bullying. Palgrave Macmillan, New York. P.2-3

Akhtar M. W, Ghufran .H, Fatima. T. (2017) The Effect of Emotional Intelligence on Turnover Intentions; The Role of Employee Well-being, Engagement and Perceived Organizational Support. Jinnah Business Review, Vol. 5, No. 2,

Edogbanya, V.O \& Momodu, A (2019) Organizational Cynicism and Employee Commitment amongst Employees of Deposit Money Banks in Lokoja. Fudma International Journal of Social Sciences (fudijoss), vol. 1 no. 2

Edlp S.M \& Alev .S.(2016) The Influence of Workplace Bullying on Employee's Job Performance, Job Satisfaction and Turnover Intention in a Newly Established Private Hospital , International Review of Management and Business Research Vol 5

Faran R. (2018) Impact of Workplace Bullying on Job Performance and Job Stress. Journal of Management Info (JMI) ISSN:2313-3376 www.readersinsight.net/jmi.

Ghadeer M.E (2016), The Impact Of Organization Cynicism On Organization Commitment And Job Satisfaction, https://www.researchgate.net/publication.

Hobfoll, S. E., Halbesleben, J., Neveu, J. P., \& Westman, M. (2018). Conservation of Resources in the Organizational Context: The Reality of Resources and their Consequences. Annual Review of Organizational Psychology and Organizational Behavior, 5, 103-128. https://doi.org/10.1146/annurevorgpsych-032117-104640

ECRTD-UK https://www.eajournals.org/

ULR: https://doi.org/10.37745/ejbir.2013 
European Journal of Business and Innovation Research

Vol.10, No.1, pp. 18-33, 2022

Print ISSN: 2053-4019(Print),

Online ISSN: 2053-4027(Online)

Hutchinson, M., \& Jackson, D. (2014). The Construction and Legitimation of Workplace Bullying in the Public Sector: Insight into Power Dynamics and Organizational Failures in Health and Social Care. Nursing Inquiry, 22, 13-26.

Hobfoll, S. E. (1989). Conservation of resources: A new attempt at conceptualizing stress. American Psychologist, 44, 513-524. https://doi. org/10.1037/0003-066X.44.3.513

Jillian R. Y. (2018). Workplace bullying: ignoring the behavior is the same as condoning the behavior. Journal of Management and Marketing Research Vol21

Jayasekara .P. \& S. M. Seneviratne (2019) Organizational Cynicism and Employee Performance:

Evidence from a Sri Lankan Audit Sector. Annals of Management and Organization Research (amor) ISSN: 2685-7715, Vol 1, no 2,

Lubna A. B, Engy S.A \& Ghadeer M.B (2018) analyzing the effect of organization cynicism on intention to leave: a case study on nola cup cakes . Iosr Journal of Business and Management, Volume 20, issue 6. www.iosrjournals.org

Leymann, h. (2008). The content and development of mobbing at work.. European Journal of Work and Organizational Psychology, Vol 5(2),

Khaled A.\& Haneen O. (2017) The Influence of Work Environment on Job Performance: A Case Study of Engineering Company in Jordan. International Journal of Applied Engineering Research ISSN 0973-4562 Volume 12.

Kuo, C.C., Chang, K., Quinton, S., Lu, C.Y., and Lee, I. (2015). Gossip in the workplace and the Implications for HR Management: A study of Gossip and its Relationship to Employee Cynicism. The international Journal of Human Resource Management, Vol 26 (18),. Https://doi.org/10.1080/09585192.2014.985329

Nair, P. \& J.T. Kamalanabhan, (2010). The Impact of Cynicism on Ethical Intentions of Indian Managers: The Moderating Role of Seniority. Journal of International Business Ethics, $\operatorname{Vol} 3(1)$.

Niharika S. (2014) Employee Turnover and Retention: An Overview. International Research. Journal of Management Science \& Technology http://www.irjmst.com

Noermijati, N., \& Azzuhri, M. (2018). Analysis of Transformational Leadership Effect towards Organisational Citizenship Behaviour Mediated by Organisational Commitment In The Heritage Hotel. International Journal of Monetary Economics and Finance, 11(3), 298306

ECRTD-UK https://www.eajournals.org/

ULR: https://doi.org/10.37745/ejbir.2013 
European Journal of Business and Innovation Research

Vol.10, No.1, pp. 18-33, 2022

Print ISSN: 2053-4019(Print),

Online ISSN: 2053-4027(Online)

Mariya R, Usman G (2014) Effect of Workplace Bullying on Turnover Intention of Faculty Members: A Case of Private Sector Universities of Khyber Pakhtunkhwa, Pakistan. Business \& Economic Review: Vol. 6,

Muhammad A .K. (2014) Organizational cynicism and employee turnover intention: evidence from banking sector in Pakistan. Pakistan Journal of Commerce and Social Sciences, Vol. 8 (1)

Margaret R. K.(2007). The Complete Guide to Understanding, Controlling, and Stopping Bullies

\& Bullying at Work. Atlantic Publishing, Inc. United State Accessed 10/07/2021

Maria R. H, Muhammad Z.\& Shahpara R. (2018) The Impact of Workplace Bullying on employee cynicism with mediating role of psychological contract. International Journal of Academic Research in Business and Social Sciences Vol. 8, no. 8, ISSN: 2222-6990

Ozler E., Derya, A., Giderler, C., \& Sahin, D. (2010). Örgütlerdesinizmgüvensizliklemibulaşir? Organizasyonveyönetimbilimleridergisi, 2(2), 47-57.

Omar T. \& Zineb I. (2019) Firm Performance: Definition and Measurement Models, European

Scientific Journal Vol 15 DOI: 10.19044/ESJ.

Rehna, M., Iqbal M. Z., Fatima, A., \& Nawab, S. (2017). Organizational cynicism and its relationship with employee's performance in teaching hospitals of Pakistan. International journal of economics and management science 6(3), 1-6.

Seifolahi, N., Hassanzade, T. (2019). Investigating the Effect of Organizational Cynicism on Workplace Bullying. Transformation Management Journal, Vol10(1),Doi: 10.22067.

Stanley, D. J., Meyer, J. P., \& Topolnytsky, L. (2005). Employee Cynicism and Resistance to Organizational Change. Journal of Business and Psychology, Vol19(4).

Seifolahi N, \& Hassanzadeh T (2018) Investigating the Effect of Organizational adikCynicism on Workplace Bullying. Transformational Management Journal (journal of management research) spring-summer volume 10 , number 1 (19)

Shafique-ur R , Rapiah M. \& Hazeline.A.(2019) The Mediating role of Organizational Capabilities between Organizational Performance and its determinant Journal of Global Entrepreneurship Research vol 9

Shehnaz B \& Sadia.M. (2013) Impact of Workplace Bullying on Organizational Outcome, Pak J Commer Soc Sci Pakistan .Journal of Commerce and Social Sciences 2013, Vol. 7 (3), 618-627 accessed 19/07/2021

Saeed, I., M. Waseem, S. Sikander,\& M. Rizwan. (2014). The relationship of Turnover Intention with Job Satisfaction, Job Performance, Leader Member Exchange, Emotional Intelligence and Organizational Commitment. International Journal of Learning and Development 4 (2). DOI: 10.5296/ijld.v4i2.6100.

ECRTD-UK https://www.eajournals.org/

ULR: https://doi.org/10.37745/ejbir.2013 
European Journal of Business and Innovation Research

Vol.10, No.1, pp. 18-33, 2022

Print ISSN: 2053-4019(Print), Online ISSN: 2053-4027(Online)

Swathi. K, \& Nagachandra R. C, (2017) Identified the Effect of Work Place Bullying on Job Satisfaction and Organisational Productivity - An Empirical Study, International Journal of Science Technology and Management Vol 6 www.ijstm.com

Tomal, D.R. \& Jones, K.J. (2015), "A comparison of Core Competencies of Women and Men Leaders in the Manufacturing Industry", The Coastal Business Journal, Vol. 14 No. 1, pp. 13-25.

Tandung J.C. (2016) the Link between HR Attributions and Employees' Turnover Intentions. Gadjah Mada International Journal of Business Vol. 18, No. 1

Wageeh A. N \& Belal A. K ( 2013) The Impact of Organizational Cynicism on Organizational Commitment: An Applied Study on Teaching Hospitals in Egypt. European Journal of Business and Management. Vol.5, no.12, .

ECRTD-UK https://www.eajournals.org/

ULR: https://doi.org/10.37745/ejbir.2013 